Vol. 4, $n^{\circ} 2 \mid 2000$

Varia

\title{
Crime, Identity and Power : Stories of Police Imposters in Nazi Germany
}

\section{Robert Gellately}

\section{(2) OpenEdition \\ 1 Journals}

Electronic version

URL: https://journals.openedition.org/chs/821

DOI: $10.4000 /$ chs. 821

ISSN: 1663-4837

Publisher

Librairie Droz

Printed version

Date of publication: 1 June 2000

Number of pages: 5-18

ISBN: 2-600-00477-7

ISSN: 1422-0857

\section{Electronic reference}

Robert Gellately, "Crime, Identity and Power : Stories of Police Imposters in Nazi Germany", Crime, Histoire \& Sociétés / Crime, History \& Societies [Online], Vol. 4, n² | 2000, Online since 02 April 2009 connection on 22 March 2022. URL: http://journals.openedition.org/chs/821 ; DOI: https://doi.org/ $10.4000 /$ chs.821 


\title{
Crime, Identity and Power: Stories of Police Imposters in Nazi Germany
}

\author{
Robert Gellately'
}

This article is based on research for a larger project on the Nazi police and German society. In the course of studying rare Gestapo files that survive for only three regions of the country, I was struck by one case in which a man was caught by the police and charged with the crime of impersonating a Gestapo official. In subsequent research, I found nearly 150 additional dossiers of people who were accused or suspected of the crime of impersonating a police official, usually a member or officer in the Gestapo. In this essay I map out some of the contours at the grassroots level of the timing, nature, extent, and variety of motives of these impostors, and offer some general reflections about this crime in the Third Reich.

Cet article s'inscrit dans un projet de recherche plus ample portant sur les rapports entre la police nazie et la société allemande. En examinant les rares dossiers de la Gestapo, qui n'ont subsisté que dans trois régions du pays, $j$ 'ai été frappé par une affaire dans laquelle un homme fut arrêté par la police et mis en cause pour l'infraction d'usurpation de la qualité de fonctionnaire de la Gestapo. En poursuivant ma recherche, j'ai découvert près de 150 autres dossiers relatifs à des usurpations de la qualité de policier, en général de la Gestapo. Dans cet article, j'essaie de montrer concrètement la périodisation, la nature, l'étendue et les différents motifs de ces impostures, et je présente quelques réflexions générales sur ce crime sous le Troisième Reich.

7 his paper is based on my research for a larger project on the Nazi police and German society ${ }^{2}$. The main sources I am using are the dossiers drawn up by Hitler's notorious Secret Police - or Gestapo. Most such files were destroyed at the end of the war in an attempt to cover up what had happened, but three large collections survived and are located in the archives of Düsseldorf, Würzburg and Speyer ${ }^{3}$.

Robert Gellately is Strassler Professor in Holocaust History in the Department of History, Clark University, Worcester, Massachusetts. He has published The Gestapo and German Society: Enforcing Racial Policy, 1933-1945 (Oxford University Press, 1990). His latest book is Backing Hitler: Consent and Coercion in Nazi Germany (Oxford University Press, forthcoming in 2001). Recently he also co-edited a collection of essays with Nathan Stoltzfus, Social Outsiders in Nazi Germany (Princeton University Press, forthcoming in 2001).

2 For an introduction see my Gellately (1990). The next volume in these studies is Gellately (2001).

3 Düsseldorf has a total of 70,000; Würzburg has 19,000 ; and Speyer 12,000 or so Personalakten. The files pertain not only to the cities, but to the region (Regierungsbezirk) which used to constitute Gestapo(leit)stellen. These are the only files to survive the war. Footnotes use abbreviations: $W=$ Staatsarchiv Würzburg; $S=$ Landesarchiv Speyer; $D=$ Hauptstaatsarchiv Didsseldorf; each letter is followed by a Gestapo file number. Also used is $\mathrm{BAB}=$ Bundesarchiv Berlin. 
As I read through these files, I was struck by one case in which a man was caught by the police and charged with the crime of impersonating a Gestapo official. The charge was called «Amtsanmaßung», which is to say, imposture, and in this event, the accusation was of assuming or usurping the identity of an office-holder. In subsequent research, I found nearly 150 additional dossiers of people who were accused or suspected of the crime of impersonating a police official, usually a member or officer in the Gestapo. In this paper I want to map out some of the contours at the grassroots level of the timing, nature, extent, and variety of motives of these impostors, and at the end offer some general reflections about what does in fact seem to be an apparent growth of this crime in the Third Reich.

\section{1. - LEGAL BACKGROUND}

The crime of « impersonating public officials » (Amtsanmaßung) was touched on in Roman Law in the context of lèse-majesté or treason, and over the centuries it was introduced in the law codes of the German states to protect the integrity of public offices (Ämter) as they were created. By the middle of the 19th century most German states had a stipulation in their penal codes making it a crime «to pretend to exercise a public office ${ }^{4}$.

The formulations already contained in Prussia's famous law code (Allgemeines Landrecht) from the end of the 18 th century, were made more precise in the Prussian Penal Code of 14 April 1851. The former prosecuted Amtsanmaßung only when fraud or private damages also were involved; otherwise the crime was prosecuted under civil law. At any rate, by the mid-19th century in Prussia, the crime was situated in Section 7, "Crimes and Offenses against Public Order». "Impersonating a Public Official» was said to be «whoever, without authorization, undertakes to exercise the duties of a public office or to commit any act which may only be done by authority of a public office». This definition was taken over as Paragraph 132 of the German Penal Code of 15 May 1871, and remained unchanged until the Nazi era.

If we jump ahead to 9 April 1942, we can note that Hitler's regime issued an "Ordinance for Broadening and Sharpening Legal Protection against Impersonating Public Officials ». There were two main revisions: First, the death penalty could be used in serious cases, with harsher imprisonment (Zuchthaus) even for minor ones. Prior to 1942, the maximum penalty was but one year (today it is two years) in jail (Gefängnis) and/or a fine ${ }^{5}$. Changes in 1942 reflected Nazi legal theorists' view that those guilty of serious crimes should not be punished by lengthier, hence costlier prison terms, but be eradicated if their «healing» was considered impossible 6 . The new ordinance also was designed to deal with a specific problem, namely the perceived growth in the number of impostors, and sharper punishment was supposed to act as a deterrent. A second modification was the specification of the "public

\footnotetext{
4 The law also protected professionals, such as doctors, lawyers, and titles like professors, clergy and the nobility. See Klaus Herrmann (1934, p. 1 ff.).

5 The 1942 Ordinance dropped the fines.

6 Roland Freisler, quoted in Werle (1989, pp. 266-267).
} 
office» $(A m t)$. Unlike earlier, the new ordinance singled out the officials covered by Paragraph 132 to be «members of the German police or one of its auxiliary organizations, or [...] members of the German Wehrmacht ${ }^{7}$. Thus, the Nazis responded not just to fake officials of all kinds, but to specific ones ${ }^{8}$.

One of the only historians to remark on these changes in the law passes over them briefly, suggests that the innovations were not related to events in the war, and notes that the ordinance was a «remarkably late» recapitulation of ideas contained in legal provisions already on the books ${ }^{9}$. An insider suggested at the time that sharper punishments were needed against those who "repeatedly " disguised themselves as members of the police or Wehrmacht, and who shook public confidence and social respect for these institutions, which in turn caused social anxiety and insecurity ${ }^{10}$.

I want to offer a more specific explanation for this turn of events ${ }^{11}$. To reiterate: this kind of imposture would seem to have been uncommon both before 1933, as apparently it was again after $1945^{12}$, so that a potentially interesting question for the social historian of crime is raised by the large number of imposters in the Third Reich.

Caution is advised here, of course, given the relatively small sample of cases that I found in the surviving Gestapo dossiers. Even if we admit that the number of imposters was and remained small in the Third Reich, the very fact that men, boys and a few females dared to present themselves in public as officials of the notorious Gestapo, suggests that not everyone was cowed down by the repressive system. They all did not merely follow orders meekly, but there were some unconventional people who continued to assert their own personalities and even capitalized on the Gestapo's reputation. As historians we have certain expectations about behaviour in the Nazi «police state», and the imposters do not fit that picture. These people dared to take advantage of new police powers for the most part for entirely selfish reasons, and they continued to do so when getting caught became as good as a death sentence. This behaviour was only very rarely «resistance», but more often the imposters followed their own egocentric drives.

At any rate, I was quite surprised to find what seemed to me a large number of men and women suspected of «impersonating officials» in the regional archives of Düsseldorf, Speyer, and Würzburg. As the number of impostors who were caught in these districts rises and declines at about the same time, I would suggest with all due caution, that there was something close to a national pattern. Obviously, a larger but unknown number of other people perpetrated the same crime, but were never caught. Most of those who were discovered, pretended to be in the Gestapo, less frequently in the Kripo. Until 1936 there was a maximum of six cases in only one year, but in 1937 numbers increased, when there were eleven; in 1938, there were

7 Reichsgesetzblatt, T. I, 174-175. The «office» is not defined in the current German penal code.

8 Ibid., para. 3.

9 See Werle, (1989, p. 417).

10 Ministerialrat Rietzsch (in 1943), cited in ibid., pp. 417-418.

11 There were three offenses subject to the death penalty in 1933 ; by 1939 there were 25 , and this increased during the war. See Lothar Gruchmann (1988, p. 1130).

12 See Claus Arved Boole (1966, p. 13). Para. 132 is not mentioned in published statistical summaries. Fraud - para. 263-265 - was considered a separate matter and tracked in the statistics. 
fourteen and in 1939, the largest yearly number, no less than thirty-eight people were apprehended. There were twenty-six individuals who were picked up the next year, followed by twenty-two in 1941, and eight in 1942 - the year in which the death penalty was introduced for the crime. In 1943 another eight were arrested, but by 1944 the number fell to six. No dossier of impostors has turned up for 1945 in these materials.

\section{2. - EARLY FAKE OFFICIALS}

One of the earliest cases of someone assuming the identity of an official came from Würzburg in August 1933. Andreas Wilmars, twenty-five years of age, was arrested for claiming to be a member of a Nazi Party spy network; it would not be his last such pretence ${ }^{13}$. In Krefeld, twenty-year-old Heinrich Offe was caught in October 1934 when he claimed membership in what he called «Department 7», of the «Prussian Criminal Police». A member of the SS, he forged police credentials with the help of a comrade (also apprehended). He claimed to be forming a secret police organization and was recruiting members. The two were portrayed in the press as SS men trying to translate a detective novel into reality ${ }^{14}$.

In Essen-Mitte on 25 November 1935, thirty-seven-year-old Michael Schad was reported to the Gestapo. The self-described merchant had presented himself as «a trusted official of the Gestapo.» He told neighbours he was in charge of surveillance of their apartment, but in fact used his "position» in an on-going conflict with them ${ }^{15}$. Evidence turned up which showed that this was not the first time Schad had impersonated a Gestapo official ${ }^{16}$.

In the early years it was not only Nazi and SS members who were caught, but also non-Nazis, including left-wing activists, who tried to harness police power for purposes of their own, such as to search the apartments of their political enemies ${ }^{17}$. Simple drunkenness also played a role at times, as when on 17 October 1936 a fortythree-year-old roofer in Essen, once a member of the SA, quite improbably announced to one and all in a pub that he was in the Gestapo ${ }^{18}$.

Impostors began to appear with increasing frequency in police dossiers in the years after 1937, most of them «ordinary » Germans from all walks of life without official positions and not even in the Nazi Party. There were some examples of men in the SS who impersonated police officials. Why? For one thing, it was not clear

13 He was suspected of carrying out «a whole series» of crimes, threatening people with a pistol, and was placed in «protective custody» until October, 1933. In March 1937, he was denounced for claiming to be an SS-Oberscharfuhrer. See W 17274.

See D 50108 ; he was sentenced to two months Gefängnis.

15 He implicated others in «crimes », for example, by suggesting that a (female) neighbour kept social contacts with a Jewish woman.

16 The case went to St.A. Essen, charges were dropped (28 July 1936) as there was no evidence he gained personally. See D 25206.

17 In Rellinghausen (May 1933), two KPD members, workers (late 20s), said they were from the police to search an apartment. They were caught, placed in "protective custody» and released before Christmas 1933; see D 52725. See also. W 8768.

18 He was barred for life from the SA. See D 26892. In Würzburg, (November 1937), a male drank nine Schoppen Wein, and claimed to be in the police. He was reported, but nothing happened. See W 5545. For false accusations, see S 3550; Landau 25 Jan. 1937. 
what precise role the SS as SS had in the Third Reich, and their lack of « executive » police powers ${ }^{19}$ may have induced some SS members to pretend at being policemen $^{20}$.

If we look at the case of Hans Peter Jahn, seventeen years old in July 1937, we can see how materialistic motives tempted him to take on the identity of a Gestapo official. He heard about the murder of a young girl in a small town, and wanted to collect the reward offered for capturing the perpetrator. Even though he dressed in SS uniform and carried false identity papers making him out to be twenty-two instead of seventeen, Jahn still looked too young for the part. He managed to dupe many people, including Nazi officials, the local gendarme, and the victim's next of kin, but was eventually apprehended by the Essen homicide squad in charge of the investigation. It turned out that this was not Jahn's first impersonation. Born into the Duisseldorf middle classes, he lived with his divorced mother, a druggist. At the time of his arrest, his father was no less than the Police President of Halle/Saale. A court appointed physician said that the boy had a tendency to «deceitful fantasies». Sentenced to six months in jail, including time already served, he was put on probation, and when released, he illegally left Germany and joined the French Foreign Legion ${ }^{21}$.

In the late 1930s, Gestapo headquarters in Berlin grew concerned about the increasing number of police impostors. In a letter of 18 December 1937, Berlin advised regional Gestapo to place anyone suspected of impersonating police officials in "protective custody " if there were insufficient grounds for an arrest. The note observed that « in the last while » the number of police impostors had increased, and steps had to be taken. In early 1938, a similar letter went from Kripo headquarters to the regional $\mathrm{Kripo}^{22}$. These notes indicate either that the number of imposters really was growing, or that in the minds of the Nazi police, even a few imposters were too many, and all of them had to be crushed.

Growth of imposture from 1938 into the early war years - or the perception of such growth in the minds of leading Nazi police officials - can be interpreted in various ways. If the number of impostors was really increasing, that would suggest that even as the reputation of the new police for arbitrariness grew, that very reputation provided a key structural precondition for the emergence of still more imposters. Police officials in Berlin were aware of this development when they wrote in one of their own journals that certain «criminal elements » tried to take advantage of the «special authority or competence» of the Security Police (ie. Gestapo and Kripo). Because such acts undermined their reputation, police were encouraged to seek the harshest punishments and to inform the population in some way of what happened ${ }^{23}$.

19 Members of the SS lacked «executive» powers: they could not legally search, confiscate, interrogate or arrest.

20 SS Scharfïhrer Alfons Klose in Kirchheimbolanden unemployed and in conflict with Nazi officials, tried (August 1935) to pressure them by claiming to be (Beauftragter) of the Gestapo. He was reported to the Gestapo by an SA-Sturmführer, who said this behaviour would «discredit the state and the Party $»$. Nothing happened to him in this file. See S 5100.

21 He was sent to jail (Gefängnis). Death was later reported from North Africa (28 February 1939), cause unknown, but there are hints he had twice attempted to desert. See D 3600.

22 Schreiben, 7 January 1938, in BAB : R58/473, B1. 61-62.

23 See Mitteilungsblatt des RKPA. Juni 1939; in BAB : R58/RD19, Bl. 46. 
The Gestapo dossier in Speyer on Thomas Sielbert (b. 1896) runs to nearly 400 pages $^{24}$. When arrested in late December 1938, he was characterized by the Gestapo in Ludwigshafen as a man who combined the traits of chronic complainer, irresponsible chatterbox and conscienceless denouncer. He boasted in public of his role in the pogrom of early November 1938, claimed to be in the Gestapo, and even whispered that he knew secret "details about the Gestapo " ${ }^{25}$. This was the last straw for the police, who arrested him and sent him to a concentration camp ${ }^{26}$. In the same month that Sielbert was picked up, an even less likely pretender was arrested nearby for claiming to be a «detective». Jakob Mauser was a publican and a retired (in 1935, due to «illness») Hauptwachtmeister who was picked up for attempting to extort money from shopkeepers. Luckier than Sielbert, he was merely given a «warning ${ }^{27}$.

Who were the victims of all these crimes? The answer is that they ranged across the social spectrum. However, officially anathematized groups, like the Jews, were especially vulnerable ${ }^{28}$. When Nazi anti-Semitism grew at the end of 1938 and into 1939 , Jews were more exposed not only to the Gestapo, but also to the fake policemen. How the Jews suffered at the hands of imposters - most of whom had nothing to do with the Nazi Party nor the German state - can be seen in a number of dossiers. For example, after Kristallnacht a Kurt Anwaerter (b. 1910) searched out Jews, pretended to be a member of the Gestapo, and he «fined» them various sums. Nothing is contained in his dossier of his fate ${ }^{29}$. A similar case was reported in April 1939, when a man claiming to be a «detective» appeared with a revolver at the home of two Jews in Mainstockheim. He «confiscated» $3320 \mathrm{RM}^{30}$. There was a lengthy dossier of a truck driver from Landau, Friedrich Schulze (b. 1918), whom an elderly Jewish woman (b. 1876) reported had claimed to be in the Gestapo, was armed and had searched her apartment on 28 January 1939 . He took notes of what happened to her during Kristallnacht, and «confiscated» $40 \mathrm{RM}$. and some jewellery. Apparently this man had used a similar scheme against other Jews in the area, and was soon charged on eight counts of impersonation, including membership in the Gestapo and Kripo, being a «representative» of a Party boss, and «leader» of the Hitlerjugend $(\mathrm{HJ})^{31}$. The favourite target of his chicaneries were the Jews. He was charged with armed robbery, extortion, and related matters. At his trial on 13 February 1940, he was found guilty and sentenced to ten months (Gefängnis); given time already spent in custody, the court declared his sentence to be $«$ completed $»^{32}$. The Gestapo was far from satisfied with this verdict, and «corrected» it by referring to a new directive (28 March 1939) on «false police officials» which stated that on

\footnotetext{
24 Unemployed, he had a lengthy police record before 1933.

25

Two men in 1 to search the synagogue. A woman, after demanding papers, called the Gestapo. The men were tried (AG) fined $120 \mathrm{RM}$ and given thirty days (Gefängnis) See W 4579 and W 16184. See another case (May 1933) W 13996.
}

29 See D 11103.

30 See W 5547.

31 He was taken into custody (20 February 1939) and confessed.

32 See S 3873. 
completion of a court-imposed sentence, such persons were to be placed in «protective custody» - that is sent to a KZ for a «longer period.» That move cost Schulze his lif ${ }^{33}$. In hopes of deterring such impostors, more details of the cases were published in the press ${ }^{34}$.

\section{3. - IMPOSTORS AND THE WAR}

The coming of the war led to a radicalization of all aspects of the police and surveillance system and an increased bloody-mindedness on the part of the police and the courts. Curiously, there was a parallel growth in the number of Gestapo impostors, or at least more people were caught trying to capitalize on unchecked police powers. With the outbreak of war, civilian life was more regulated than ever, and these new measures again also opened up areas of social life that impostors could exploit. Shortly before the war, the Nazis tried to deal with issues of personal identification, and on 6 January 1938 introduced a system (which survived for a time after 1945). It was designed «to facilitate the Security Police in their battle against law breakers ${ }^{35}$. The identification system, sharpened again on 6 September 1939 under the war measures acts, was no sooner in place than forgers began capitalizing upon $\mathrm{it}^{36}$.

Another new law which was promptly taken advantage of for personal gain, was one from early September 1939 that outlawed listening to enemy radio broadcasts. That measure was not only exploited by petty denouncers, but also by police impostors. For example, newspapers along the Rhine carried an account of fifty-sevenyear-old Heinrich Michel who, on a visit in Wuppertal before Christmas 1939, told a female shopkeeper he was on assignment for the Gestapo to catch those listening to foreign radio. He said «reliable sources» told him what she and her family were up to, but that he would be willing to overlook it if she agreed in writing never to listen to foreign radio again. She would sign nothing, even after he made a second try. Michel returned again six months later, to tell her that «colleagues » in the police knew she was listening to the BBC. He added that in a similar case he had been offered 50,000 R.M. «hush money.» That story made her think he was a swindler, and she tipped off the police. He was soon caught and given two years imprisonment (Zuchthaus). The newspaper story on the case concluded that this ought to act as encouragement to the people to inform police about their suspicions, ${ }^{37}$ but that certainly did not always happen ${ }^{38}$.

33 He was released (13 February 1940) «through an oversight». With Himmler's (the RSHA) authorization in their pocket, the Gestapo in Neustadt used its «ability to decide » to rearrest him on 7 May 1940. He was sent to Mauthausen (20 June 1940) from where (11 October 1940) his death was reported. See $S 3873$.

34 Name and address of the subject was also to be published. See BAB: R58/473, Bl. 104.

35 This was the Reichsmeldeordnung. See Aly and Roth (1984, p. 40). They mention (tongue in cheek) that this system was one of the «accomplishments» of Nazism. A registration/internal passport system was introduced in France in the latter 19th century: see Corbin (1990, p. 468).

36 See Grunberger (1977, p. 347).

37 He insisted at his trial (Düsseldorf SG) that the family listened to the BBC. He was found guilty, also of taking advantage of war measures. See S 1995.

38 A man (b. 1905) was (23 Nov. 1940) on the train from Gemünden to Lohr. When he could not find a seat he roared: "You'll find out soon enough with whom you are dealing. I am from the Geheime 
Some impostors took hair-raising chances. A prominent example was Heinz Schilling, thirty-four years old in January 1941 when his activities in the RheinRuhr area were uncovered. Essen Kriminalkommissar Peter Hafer reported at length on the case in a police journal, where he said the man had a "claim to fame», even of «being worthy to be placed on a pedestal alongside the Captain of Köpenick»; both exhibited «a surprising and unheard of measure of audaciousness and coldbloodiness»; both showed «personal adroitness and cunning, as well as quick improvisation ». Indeed, there were two famous examples of imposters in German history from the pre-1914 era. The phrase "clothes make the man» or «Kleider machen Leute» - comes from Gottfried Keller's mid-nineteenth century novella about a poor tailor who, upon arriving in a small town is taken to be a Polish Count Strapinski. Apart from a nobleman's cloak, "Count» Strapinsky's identity is constructed by the local people who attribute «noble» characteristics to his every act. Another imposter is portrayed in Carl Zuckmayer's play, Der Hauptmann von Köpenick ${ }^{39}$. Based on a real-life case from 1906, a down-on-the-heals (cobbler) Wilhelm Voigt is transformed merely by donning a Captain's uniform. The exercise of the social powers of «Count» and «Captain » derived from social projections and the authority attributed to the nobility and military at the time. Both stories became so popular in Germany because they mocked higher authority, but also poked fun at the willingness of some citizens to let themselves be swept away or bowled over by that authority. Thus the stories are also suggestive of how power and especially the power of the uniform is constituted socially at the micro level.

In the case at hand from the Third Reich, the version of «Köpenickiade» [sic !], ended in failure sooner, and there was less public sensation aroused than over the original. In spite of the «reprehensibleness» of Schilling's «numerous» deeds, the Nazi policeman who wrote of the case felt that «one had to recognize» the man and give him respect as «a master of fraud». What made Schilling's exploits seem like a «Köpenickiade», was that he did not shrink from victimizing officialdom, and even went «into the lion's den» itself. Schilling's schemes at the end of January 1941 began when he appeared in Düsseldorf with the identity of State Attorney $\mathrm{Dr}$ Schmidt. He telephoned Essen's Deputy Police President to ask that a car be placed at his disposal to pick up two thieves in a town near by. Told that such a request must be made in writing and presented personally, «Dr Schmidt " went to the courthouse, claimed he was a member of the Berlin Gestapo, and asked to have an official request for the car typed for him on official stationary. When he returned to the Police Presidency, he was again told that it was impossible for him to use the car. «Dr Schmidt» insisted, renewed his demands face to face with the head of the Essen Kripo, and got his way, save that the head of detectives insisted that one of his men go along to make the arrests.

Although the Essen Kripo knew «Dr Schmidt» certainly must have shown his identity papers to the Deputy Police President, "merely for the sake of formality », they asked him once again for his papers. This was a critical situation, for all Schilling had was the forged letter not half an hour old, and this could be seen as a fake. «Dr

Staatspolizei and I'll show you...» Reported, he was placed in «protective custody" (27 April 1941). Because he did not act on the impersonation the matter was dropped (14 May 1941). See W 12258; for another eg. (15 June 1938), see $S 4545$, the male (b. 1912) was not caught.

39 See Zuckmayer (1961). The play was finished in 1931, but made Zuckmayer famous after 1945, especially in the film version starring Heinz Rühmann. 
Schmidt» feigned «great surprise» that he could not find his «papers», and exclaimed that he must have left them at the courthouse. Kripo officials kindly offered to have the papers returned, but «Dr Schmidt» left, saying he preferred to pick them up himself. He escaped briefly, but was eventually caught, delivered to a fate unknown. What set him apart from the everyday fraud artist, at least according to the Nazi police, was that he «cloth[ed] himself in the untouchable nimbus of authority " ${ }^{40}$.

Inevitably, fake police were tempted to use their powers to take advantage of women. For example, in Remscheid during August 1941, (married) foundry worker Wilhelm Kaiserling (b. 1901) convinced several young women that he was a detective $^{41}$. He went from table to table in a cafe, saying he was going to arrest «the whole lot » of the women there, a remark that caused some to weep. He threatened one with a visit to police headquarters unless she «cooperated", and he boldly demanded sexual favours from another. None of the threats worked ${ }^{42}$, and he was arrested. He was soon released when the charges were dropped because he had not presented papers to identify himself as a policeman ${ }^{43}$.

The perceived growth of police impostors and certainly of official concern can be seen in another instruction sent from Gestapo headquarters to local police on 4 September 1941. Henceforth, anyone «who falsely presented themselves as members of the Gestapo, Kripo or in general other police officials » were to be arrested without further $\mathrm{ado}^{44}$. The discretionary powers of the police were enormous, and this new instruction added to them when it came to the impostors. In a case not unlike Wilhelm Kaiserling's (just mentioned) a little later in Würzburg in 1941, Johannes Hermann paid with his life. Hermann (b. 1882, and married), served with distinction in World War I. He was in the Nazi Party (from May 1933), since 1934 a Zellenleiter, and at the time of his arrest he worked in the municipal economic office ${ }^{45}$. At 8:30 a.m. on 10 November 1941 he went to the apartment of a divorcee in Würzburg claiming to be from the Gestapo. Though she let him into her flat, she soon grew suspicious, demanded to see his papers, and got him to leave. She reported him to the Kripo and Hermann was arrested. By 11 December 1941 he was found guilty by the court (AG), placed in "protective custody», and sent to a $\mathrm{KZ}$. He arrived at Dachau on Christmas day 1941 and was dead less than two weeks later. The entire case had run its course in under two months ${ }^{46}$.

Virtually all Gestapo impostors were male, but three females were accused of the crime $^{47}$. Two cases from 1941 turned up evidence that the women had passed them-

40 Schilling was in trouble with the law since he was twenty years old. Apprehended again in 1939, for impersonating a public official and forgery and given six years, he escaped in January 1941. There is no word of what happened after his last arrest. See BAB : R58/RD19/26, February 1942 issue, Bl. 16-18. Before 1933 he had two convictions for fraud.

42 One of the women was later arrested for refusing to work, and reported that recently she was «approached» by a police official.

43 See D 4646.

44 See S 4222 .

45 He died on 5 January 1942. See W 13919; the newspaper was the Fränkischer Volksblatt 9.1.42.

46 He had been a publican, salesman, and employee at the city health office (until 15 September 1941).

47 An «elegant dame», (b. 1899), listed as a «secretary» from Glogau, was arrested in Hamm (14 June 1938). She said she was in the Gestapo and in charge of purchasing for the Kommandantur Glogau. In various stores in Würzburg she said she was from the Air Ministry. The Würzburg Gestapo was told of her arrest, but there is nothing in the file about what happened. See W 4150. 
selves off as members of the Gestapo, but no one could prove they had tried «to commit an act which $\mathrm{m}$ [ight] only be done by authority of a public office», which was necessary to be found guilty under Paragraph $132^{48}$. In another case, a waitress, Bernhardine Jerewski (b. 1922) spoke with several HJ leaders she met in a cafe, and in passing said she was an agent of the Strasbourg Gestapo. When arrested she admitted only talking about the war, including the Gestapo's role in taking Strasbourg and Norway [sic!]. Witnesses were brought in, but only one claimed she had said she was "with the Gestapo». As she did not act on the basis her pretence, the case did not proceed to court ${ }^{49}$.

After 1941 the decline in the number of suspected impostors continued, at least to go by the localities studied here, so that there was no "objective» justification for introducing Draconian punishments in 1942, because the flood of impostors had already subsided. In spite of new punishments and publicity given to the seriousness of impersonating police officials, not everyone was deterred ${ }^{50}$. Men continued to claim membership in the police in order to take advantage of women. In Mönchengladbach on 14 July 1943 Gertrud Jensen - a married woman, husband on the Eastern Front - reported that around midnight a certain Heinrich Mocker (b. 1897) gained entrance to her residence on the pretext of being from the police and tried to convince her to have sexual relations. Although Jensen herself had an unsavoury reputation, the police found her story credible, and Mocker eventually ended up in a $\mathrm{KZ}^{51}$.

At about the same time, and not far away in Wuppertal, a similar case took place. Friedrich Heyt (married, b. 1900, war veteran and self-described mechanic), found it difficult to adjust to life after $1918^{52}$. By 1937 he had an alcohol problem, been placed in a work camp for nine months, and finally got a regular job again. At some point between his release and early 1943, Heyt decided to forge false identity papers that were inscribed with the cryptic words «Geh. Sta. Polizei $44 »$. Under police questioning later, he stuck to the story that he had just found the papers in the street. His exploits were finally uncovered on 27 April 1943, when a woman (b. 1900) reported to the Gestapo that near midnight on the 23rd, as she picked up a woman friend at a cafe, a man claiming to be a detective asked to see her papers. She tried to ignore him, and the women left with a male friend. The "policeman » followed them home, forced entry to her flat, again presented his «papers» and threatened arrest. Nothing came of all this and Heyt left. Soon afterwards, he was arrested on another matter ${ }^{53}$. Once in custody, the earlier complaint surfaced. Like other men, there is no way of knowing the full extent of his impostures ${ }^{54}$.

48 A servant (female, twenty-one years of age) dismissed for petty theft, sought revenge by telephoning (in the name of the NSDAP Ortsgruppe) with the (false) news that the husband of her (former) employer was killed in action: the news caused a nervous breakdown. The victimizer was caught and sentenced (under paragraph 132) to 1 year 6 months Gefängnis. See Boberach (1975, pp. 135-136).

See $\mathbf{S} 6324$.

A male (b. 1913) with a record, caught breaking and entering a business in Mönchengladbach in March 1944 sought escape by saying he was a Kriminalbeamter. See D 58357.

See D 5707 and D 7700 . See also D 55507.

He actually worked in a munitions factory.

The pretences were uncovered in Wuppertal during a bombing raid on Barmen 30 May 1943 ; charged with presenting himself as member of the Gestapo, six people supported the charges.

He had a short criminal record. He was found guilty of falsifying documents and impersonating an official by the AG Wuppertal (6 Sept. 1943) and sentenced to 5 months (Gefängnis), then placed in «protective custody» and released after a «warning» 3 April 1944. See D 23586. 
Matthias Petersen (b. 1918) was injured in July 1941 while serving in the Army in the war against the Soviet Union. A complaint was lodged against him with the Kripo in Trier in early September 1943 by a man whose daughter (b. 1923) met Petersen who introduced himself as a member of the Gestapo from Duisburg, saying he and several comrades were in Trier on a mission. Petersen developed a relationship with the woman, even proposed marriage, but just as quickly up and left town, and was charged with breach of promise. He was tracked to Duisburg, and arrested on 19 September 1943. Another woman added to Petersen's woes by telling the police he claimed to carry a gun and to be an agent (Spitzel) of the Gestapo. Petersen admitted only that he said he had worked informally for the secret police ${ }^{55}$, but he had done no more than approach a member of the Gestapo in hopes of becoming an agent (V-Mann). Although his services were rejected by the Gestapo, he soon began presenting himself as working for them. He was denounced on 21 October 1943 for making the claim in a cafe during an argument, information that came to the Gestapo on the same day as word about his activities in Trier $^{56}$.

There are surprisingly few Gestapo dossiers of impostors who tried to take advantage of foreign workers in war-time Germany ${ }^{57}$. We can only speculate about why this is so. One case was reported to the gendarme in a small town near Würzburg on 4 February 1944. Fridolin Ruddin (b. 1910) ${ }^{58}$ was charged with impersonating a policeman, «checking» foreign workers and taking money and a bicycle from them. He was told to return these by « another civilian»-unnamed in the fill ${ }^{59}$.

Other instances of imposture were brought to Gestapo attention in 1944, but in the space remaining I want to turn to the dossiers of Adolf Seisser (b. 1897) and Hugo Seeger (b. 1884), as this case shows another set of motives as to why ordinary people tried to tap the power of the Nazi police.

Hugo Seeger had served with distinction in World War I, and in spite of old war wounds, he enlisted again in Hitler's war, rose to the rank of Captain in the Abwehr, and left the service in July 1941 when wounded in action. Though a member of the NSDAP since 1 May 1933, the "political evaluation» in his dossier branded him unreliable and «completely uninterested in politics». His friend, Adolf Seisser was a wealthy man from a prominent Würzburg family. Like Seeger, he had voted for conservative parties before 1933 and like him, joined the NSDAP on 1 May 1933. In late 1943, Adolf Seisser's brother, Erich (b. 1899), was arrested for saying in a restaurant that Hitler was «a dog.» One of the waitresses apparently told her husband, and he in turn denounced Seisser on 27 October $1943^{60}$. The case ended up at the People's Court (VGH) which pronounced a death sentence on 12 July 1944. When Adolf Seisser heard the verdict, he went to Hugo Seeger, a friend who knew the official scene in Berlin and they discussed options with various people. The

\footnotetext{
55 The term is Zuträgerdienst.
}

The case went to court, and was postponed due to difficulties in hearing the witnesses until 5 June 1944 when he was found guilty and sentenced to 7 months (Gefängnis). Because of an injury, he was not considered fit to be sent to a concentration camp. See D 57377 and D 62412.

By August 1944, 7.6 million foreign workers were employed in the country.

He had been found guilty of various minor offenses on eleven previous occasions.

He was given eleven months for resisting arrest and public mischief; he was then treated at an institute for alcoholism. See W 10812.

60 He was an SS-Oberscharfuihrer, and was killed in action in Normandy soon afterwards. Both women were married with children. 
upshot was that the only hope anyone saw to have the case reopened and/or to apply for clemency, would be to raise doubts about the credibility of the witnesses, or to have them recant.

The days following the attempted assassination of Hitler (20 July 1944), were dangerous times, and the terror system was on full alert. Nevertheless, Seeger and Seisser set out on their mission from Berlin. They arrived at the scene of the crime in the town of Zimmern on $29 \mathrm{July}$, and questioned local officials, (including the gendarme, Kreisbauernführer, and a retired Kriminalkommissar). They repeatedly asserted that the courts were passing «astronomical numbers » of faulty death penalties, and claimed to have been sent to investigate Erich Seisser's case. They finally got in touch with the Mayor and Party boss (Zellenleiter) Binder when they returned a third time to the small town. On request, Seeger showed his papers to the mayor who gave them a perfunctory glance like everyone else. The Mayor was asked about the background of the denouncers' family, for rooms to carry out interrogations, and even to have them all summoned for interrogation.

The mother of the family was questioned first. She and her husband owned the restaurant where Erich Seisser made his treasonous remarks. She was asked about the conversation between her daughter, Frau Vogel and Seisser, witnessed by another daughter Frau Schmidtz. Seeger said something was not quite right about the testimony, and tried to intimidate her (eg. he said that as an officer in the Abwehr he had personally executed «about 3,000 people»). As it happened, one of the witnesses, the waitress Vogel had already left town. Frau Schmidtz, interrogated in front of the Mayor, would not change her story, and said merely that she had not denounced Seisser at all, but had told her husband what happened, and it was he who made the report. Fake police official Seeger remarked caustically: «Well, don't you make a pretty pair!» He also accused her of making false charges. Finally the Mayor's suspicions began to dawn, not least he later said, because of Seeger's methods and some of his remarks. He called Würzburg and arrests quickly followed. By 15 December 1944, both men were sent to trial and both found guilty as charged. Seeger, considered the main culprit, was sentenced to death ${ }^{61}$. However the execution was commuted on "authority of the Führer» (19 February 1945) to twelve years imprisonment. Adolf Seisser, said to have played a more passive role, and to have been motivated by concerns about his brother, was sentenced to four years. The files are silent on whether Erich Seisser was ever executed ${ }^{62}$.

\section{4. - CONCLUSIONS}

First of all, it is important to situate police impostors in the context of the dynamic interaction of police and society of the times. The emergence of impostors indicates that the social and political effects of the terror system did not always conform to the neat blueprints drawn up in Berlin. In keeping with some of the insights offered by Michel Foucault on power, the routine functioning of the

61 Much was made not only of the impersonation of a public official, but also of remarks made about the VGH, including those made in custody to another prisoner.

62

See W 14129; W 14062. 
Gestapo and Kripo, even in their heyday, was not merely repressive, but also creative or productive in several interrelated ways ${ }^{63}$.

The Gestapo and Kripo were repressive and they were provided by the regime with new, nearly unfettered executive powers. Yet it is also clear that this police would have been hampered without cooperation from the society of which it was a part. Even a better equipped or more numerous police could not function without information from the population. Thus, the much emphasized "omnipotence» of the Gestapo was gained to a considerable degree according to the extent to which it received these tip-offs. Ordinary people, from an infinite variety of motives - some of them regarded as dysfunctional by the regime - worked as the eyes and ears of the police. Another «product» of the Gestapo's activities was, given «system-immanent" criteria, an increase in crime; new laws produced new crimes, especially during the war years. And still another «product» of the terror system were police impostors. As the Gestapo and to some considerable extent also the Kripo attained a reputation for ruthlessness, brutality and mystery, their powers and reputation not only deterred, but called forth amateur imitators. From the point-of-view of impostors, the Gestapo (and Kripo) had the additional advantage of being detectives operating mostly in civilian clothes. The reputation and ethos surrounding the police opened windows of opportunity for impostors.

Although specific personal/individual factors can be discerned in their activities - like all the actors in social history - the fact remains that because of their emergence in all three districts - and across the country - in not insignificant numbers, I want to suggest that much more than personal idiosyncrasies were involved. Structural changes in society after 1933 created conditions conducive for police impostors to emerge and operate.

To what extent can we say that police imposture of the kind we see in Gestapo dossiers was rooted in German political culture? By all accounts there were relatively few people who impersonated public officials before 1933 or after 1945. However, German society did not begin from scratch on 30 January 1933, and historians and sociologists have pointed to the various ways some persecutions of the Nazi regime were linked to the German past. If one were to take only certain fictional writings from the era prior to 1914 - only some of which $I$ have mentioned in this article - as reflecting the prestige and power conferred by uniforms, titles and social standing, then one might say that there were elements of continuity which contributed to the structural conditions which made the emergence of impostors in the Nazi era possible.

We are left to wonder whether impersonators of officials and especially of the secret police can also be found in other modern dictatorships, when the power of the police is such, that at least some ordinary people attempt to capitalize on it for purposes of their own. There are hints in recent work on the Soviet Union in the 1930s, that citizens identified with fast-talking confidence men in the literature of the day, men who could out-talk and out-think officialdom ${ }^{64}$. The wide readership of several books on this theme in Germany, even before the First World War, suggests among

63 See Foucault (1978, p. 81 ff.).

${ }^{64}$ See Fitzpatrick $(1999$, p. 222). Because social identities could have disastrous effects on ordinary people's lives in the Soviet Union, there was a great deal of «masking» and «unmasking», and Fitzpatrick examines this phenomenon at length. 
other things that there was some popular longing for resistance to «them up there ", and a yearning of the people to show they did not accept their own powerlessness. That side of imposture as a social phenomenon deserves further research.

Why the apparent decline in police impostors in the last years of the Nazi regime? It is possible that the introduction of the death penalty and the increasing propensity to use it, deterred some impostors. More likely, the attention of the Gestapo changed, and it became preoccupied with new tasks, especially to policing the vast army of foreigners in the country and keeping them isolated. Finally, fewer people may have been interested in impersonating the most blood-thirsty representatives of the Nazi regime as its legitimacy eroded. Growing out of this, the social power impostors could tap, gradually evaporated as the regime struggled toward its apocalyptic end ${ }^{65}$.

Robert Gellately
Center for Holocaust Studies
Clark University
950 Main Street
Worcester, Mass. 01610-1477
USA
rgellately@clarku.edu

\section{REFERENCES}

Aly, G., and Roth, K.-H., Die restlose Erfassung,Berlin, 1984.

Arved Boole, C., Die Amtsanmaßung, Phil. Diss, Hamburg, 1966.

Boberach, H., (ed.), Richterbriefe. Dokumente zur Beeinflussung der deutschen Rechtsprechung 1942-1944, Boppard, 1975.

Corbin, A., «Backstage,» in Perrot, M., (ed.), A History of Private Life, vol, 4, Cambridge (Mass.), 1990.

Fitzpatrick, S., Everyday Stalinism: Ordinary life in Extraordinary Times. Soviet Russia in the 1930s, New York, 1999.

Foucault, M., The History of Sexuality, vol.1, (trans. R. Hurley), New York, 1978.

Gellately, R., The Gestapo and German Society: Enforcing Racial Policy (1933-1945), Oxford, Oxford University Press, 1990.

Gellately, R., Backing Hitler, Consent and Coercion in Nazi Germany, Oxford, Oxford University Press, 2001 (forthcoming).

Gruchmann, L., Justiz im Dritten Reich 1933-1940, Munich, 1988.

Grunberger, R., A Social History of the Third Reich, Harmondsworth, 1977.

Herrmann, K., Die Amtsanmaßung nach geltendem deutschen und österreichischen Strafrecht, Leipzig, 1934.

Werle, G., Justiz-Strafrecht und polizeiliche Verbrechensbekämpfung im Dritten Reich, Berlin, 1989.

Zuckmayer, C., Der Hauptmann von Köpenick: Ein deutsches Märchen in drei Akten, Frankfurt am Main, 1961.

65 For an in-depth examination of the last months of the Third Reich, see my forthcoming book, Gellately (2001). 